\title{
Utility of Kanji as Per Rasaratna Samuchchaya - An Extensive Review
}

\author{
Ankita Prajapati ${ }^{1}$, Surekha S Medikeri ${ }^{2}$, Anand Katti ${ }^{3}$ \\ ${ }^{1}$ PG Scholar, Department of Rasashastra \& Bhaishajya Kalpana, Govt. Ayurvedic Medical College, Bengaluru. \\ ${ }^{2}$ Professor and HOD, Department of Rasa Shastra and Bhaishajya Kalpana, Govt. Ayurvedic Medical College, \\ Bengaluru. \\ ${ }^{3}$ Associate Professor, Department of Samhita \& Siddhanta, Govt. Ayurvedic Medical College, Bengaluru. \\ Corresponding Author: Ankita Prajapati
}

DOI: https://doi.org/10.52403/ijhsr.20220219

\begin{abstract}
Sandhana Kalpana in Ayurveda proposes many alcoholic formulations. The medicinal values are extracted in a self-generated weak alcohol medium through fermentation. Kanji which is prepared by fermenting boiled masha dhanya with gruel of raktashali is given paramount importance. Kanji is a unique kind of formulation having vast utility. Rasaratna Samucchaya authored by Rasavagbhata emphasizes usefulness of kanji in many folds. This article is an effort to compile vast literature on kanji in Rasaratna Samuchchaya, analyse and present it systematically. The utility of kanji with reference to parada, maharasa, uparasa, sadharana rasa, loha, ratna are discussed.
\end{abstract}

Key Words: Kanji, Kanjika, Rasaratna Samuchchaya.

\section{INTRODUCTION}

Ayurveda is a life science which aims to maintain the health of a healthy individual and cure the diseases. It offers both preventive and curative methods to attain this aim. Kanji is a unique Ayurvedic fermentative preparation which comes under Sandhana kalpana. Sandhana kalpana (fermentative products) are divided into madya kalpas (alcoholic preparations) and sukta kalpana (acidic preparations). Asava and arishta comes under madya kalpana whereas preparation like souviraka, kanji, etc. comes under sukta kalpana.

Kanji is usually prepared by fermenting incompletely boiled masha dhanya with gruel of rakta shali and is routinely used for various purposes. Kanji prepared out of Dhanya is said to be jeeveniya, daha nashana, vata-kapha hara, trushnahara etc. when used internally. ${ }^{[1]}$ But the kanji explained in the paribhasa prakarana of text Rasayanasara is said to be for Dhatu shodhana (purification of metals) and other mercurial processing. ${ }^{[2]}$ Synonyms of kanji are aranala, souvira, kulmasha, abhishuta, avantisoma, dhanyamla, kunjala, kanjika. ${ }^{[3]}$ As Rasa Ratna Samuchchaya is most widely used book in Rasashastra, therefore in this article an attempt has been made to highlights the utility of kanji in various processing according to Rasaratna Samucchaya.

\section{METHODS OF PREPRATION OF KANJI: -}

1) According to Rasendra Chintamani ${ }^{[4]}$

Variety of Tusharahita dhanya (dehusked grain) is made into coarse powder form and filled in one mud pot. Water is added to this pot and left undisturbed till becomes sour. Later bark and roots of nagaramusta, bhrami, gorakhmundi, vishnukranta, punarnava, meenakshi, sarpakshi, sahadevi, shatavari, triphala, girikarni, hamsapadi, chitraka are made in powder form and added to the mud pot. This is known as Dhanyamala. It is 
used for Parada swedana processes.

2) According to Rasayanasara ${ }^{[2]}$ - The Kanji explained in the Paribhasha prakarana of the text Rasayanasara, is said to be specific for Dhatu shodhana (purification of metals) and other Mercurial processing.

Table 1, showing the ingredients and quantity for kanji preparation.

\begin{tabular}{|l|l|l|}
\hline Sl.no. & Ingredients & Quantity \\
\hline 01 & Rajika & 1 seth (ser) \\
\hline 02 & Saindhava lavana & 2 seth \\
\hline 03 & Kulattha kwatha & 4 seth \\
\hline 04 & Odana (cooked rice) & 2 seth \\
\hline 05 & Haridra churna & $1 / 2$ seth \\
\hline 06 & Vamsha patra & $1 / 2$ seth \\
\hline 07 & Shunti & $1 / 4$ seth \\
\hline 08 & Sweta jeeraka & $1 / 4$ seth \\
\hline 09 & Hingu & $1 / 2$ seth \\
\hline 10 & Masha pishta & $1 / 2$ seth \\
\hline & $*$ Approximately one ser is equal to- 960 gm. \\
\end{tabular}

Ingredients should be pounded and filtered through cloth. A mud pot smeared with Sarshapa taila (mustard oil) in its inner side should be taken and all the ingredients are slowly put inside the pot. Then 20 ser water is added to it and mixed thoroughly. Later masha chakrika are added at the end. The mouth of the pot to be sealed properly and left undisturbed for 7 days for fermentation. It usually gets completed in 4 days in summer season. Later the product is filtered through cloth and used for various mercurial processes.

Based on the reference of Rasayanasara, a study conducted at National Institute of Ayurveda, Jaipur about the method of preparation of Kanji with slight modification. ${ }^{[5]}$ Following method was adopted with ingredients as mentioned in Table 2

Table 2, showing the ingredients and quantity for kanji preparation

preparation
\begin{tabular}{|l|l|l|}
\hline $\begin{array}{l}\text { Sl. } \\
\text { No. }\end{array}$ & Name & $\begin{array}{l}\text { Quantity } \\
(\mathbf{g m})\end{array}$ \\
\hline 01 & Rajika (Brassica juncea Linn.) & 240 \\
\hline 02 & Saindhava lavana (Rock salt) & 480 \\
\hline 03 & Kulatha (Dolicus biflorus Linn.) & 480 \\
\hline 04 & Odana (Cooked rice) & 480 \\
\hline 05 & Haridra (Curcuma longa Linn) & 120 \\
\hline 06 & $\begin{array}{l}\text { Vamsha (Bambusa arundinaceae } \\
\text { Willd) }\end{array}$ & 120 \\
\hline 07 & Shunti (Zingeber officinale ) & 60 \\
\hline 08 & Jeera (Cumimum cyminum Linn.) & 60 \\
\hline 09 & Hingu (Ferola northrax Linn) & 5 \\
\hline 10 & Jala (water) & 4800 \\
\hline 11 & $\begin{array}{l}\text { Sarshapa taila (Brassica campestris } \\
\text { Linn) }\end{array}$ & Q.S. \\
\hline 12 & Masha (Phaseolus mungo Linn) & 120 \\
\hline
\end{tabular}

\section{Method of preparation-}

a) Preparation of Kulatha Kwatha- 480 gm of Kulatha was taken in a wide mouthed container and added with $3840 \mathrm{ml}$ of water (8times of Kulatha). It was kept on mandagni (mild fire) till it reduced to $960 \mathrm{ml}\left(1 / 4^{\text {th }}\right)$ and filtered and kept.

b) Preparation of Odana- 250gm of Shashtika shali was taken in a vessel and by adding $1250 \mathrm{ml}$ of water ( 5 times) it is cooked on mild fire it gets reduced to 480gm.

c) Hingu shodhana- $5 \mathrm{gm}$ of Hingu was fried in sufficient quantity $(150 \mathrm{ml})$ of ghrita.

d) Masha chakrika preparation- $120 \mathrm{gm}$ of Masha flour with little quantity of Saindhava lavana and sarshapa taila was taken in a vessel and paste was prepared from this. This paste was fried and chakrikas was made.

e) All ingredients were finely powdered

Once all the ingredients were ready, the pre-treated pot (smeared with Sarshapa taila in its inner side) was taken and $4800 \mathrm{ml}$ of water was poured into it. Then $960 \mathrm{ml}$ of Kulattha kwatha was added followed by Odana 480gm. The fried Masha chakrikas was put along with fine powder all the ingredients and mixed well. The mouth of the pot was closed tightly and left undisturbed for proper fermentation.

The study also showed the following observations:

$>$ Fermentation was completed on $24^{\text {th }}$ day when the $\mathrm{pH}$ was 3.21.

$>$ But it was kept for one more week (31 ${ }^{\text {st }}$ day) till $\mathrm{pH}$ becomes 2.91 .

$>$ The prepared kanji was golden yellow colour with pleasant odour and characteristic sour taste.

$>$ The kanji when subjected to various preliminary analyses showed that the total solids in it were $19.26 \%$, reducing sugars $2 \%$ and specific gravity was 1.039 .

$>$ The alcohol percentage was zero and even starch was absent. There was no fungus growth seen at any stage of fermentation. 
Utility of kanji- The various utility of Kanji in different mercurial processing and Indian alchemy chemistry according to Rasa Ratna Samucchaya edited and translated by Acharya Siddhinandan Mishra (RRS) ${ }^{[6]}$ and by Prof. Dattatraya Anant Kulkarni $\left(\mathrm{RRS}^{*}\right)^{[7]}$ is described below.

Rasavarga- These are eight Maharasa, viz, Abhraka (Mica), Vaikranta (Tourmaline),
Makshika (chalcopyrite), Vimala(Iron pyrite), Shilajatu (mineral pitch), Sasyaka (blue vitriol), Chapala(bismuth ore) and Rasaka (zinc ore). ${ }^{[8]}$ These eight drugs are very important in Ashtadasha Parada Samskara. Applicability of Kanji in various Rasavarga processings is shown in Table No 3

Table 3 showing the utility of Kanji in Rasavarga with Rasaratnasamucchaya reference

\begin{tabular}{|c|c|c|c|c|}
\hline $\begin{array}{l}\text { Sl. } \\
\text { no }\end{array}$ & Rasa dravya & Purpose & Method & Reference \\
\hline $\mathrm{O} 1$ & $\begin{array}{l}\text { Abhraka } \\
\text { (Mica) }\end{array}$ & $\begin{array}{l}\text { Shodhana } \\
\text { (Purification) }\end{array}$ & Abhraka patra is to be heated in intense fire and dipped in kanji for 7 times. & RRS 2/16 \\
\hline 02 & Abhraka & $\begin{array}{l}\text { Dhanyabhraka } \\
\text { (Intermediary } \\
\text { process in } \\
\text { incineration } \\
\text { Mica) }\end{array}$ & $\begin{array}{l}\text { 1-part Sudha abhraka and } 1 / 2 \text { or } 1 / 4 \text { part shali dhanya (rice grain) should be } \\
\text { mixed together and tied in a thick cloth to make a pottali which is to be } \\
\text { immersed in kanji for } 3 \text { days. On } 4^{\text {th }} \text { day pottali should be loosened slightly } \\
\text { and rubbed with hand. By this method abhraka escape out of pottali into the } \\
\text { kanji in fine powder form which has to be filtered later. }\end{array}$ & $\begin{array}{l}\text { RRS } 2 / 18 \\
\text { RRS } 8 / 33\end{array}$ \\
\hline 03 & Abhraka & $\begin{array}{l}\text { Satvashodhana } \\
\text { (purification } \\
\text { essence of Mica) }\end{array}$ & $\begin{array}{l}\text { Abhraka satva is to be boiled with amla kanji, then placed in } \\
\text { musha(crucible) along with Shodhaniya dravya kwatha }{ }^{[9]} \text { to give intense } \\
\text { fire. }\end{array}$ & RRS 2/34 \\
\hline 04 & Abhraka & $\begin{array}{l}\text { Satvamarana } \\
\text { (incineration of } \\
\text { essence of Mica) }\end{array}$ & $\begin{array}{l}\text { Abhraka satva bolus after heating in fire is dipped in Kanji. Then it is to be } \\
\text { pounded in iron kalwayantra and filtered through cloth. Then fine powder of } \\
\text { Abhraka is fried with goghrita ( } 3 \text { times). Later it is to be grinded with } \\
\text { amalakiphala swarasa or amalaka patra swarasa in khalwa yantra( } 3 \text { times). } \\
\text { After this } 3 \text { times bhavana(levigation) each with Punarnava swarasa, } \\
\text { Vasaswarasa and Kanji. This is made into chakrika form and } 10 \text { gajaputa } \\
\text { should be given. Again, 1/4th part of Gandhaka is added in } 1 \text { part of abhraka } \\
\text { satva to give bhavana with Kanji and subjected to } 10 \text { gajaputa. }\end{array}$ & $\begin{array}{l}\text { RRS 2/43- } \\
47\end{array}$ \\
\hline 05 & $\begin{array}{l}\text { Vaikranta } \\
\text { (Tourmaline) }\end{array}$ & Shodhana & $\begin{array}{l}\text { Swedana(boiling) in dolayantra with nimbu swarasa and amlakanji mixed } \\
\text { with yavakshara, sarjikshara, tankanakshara and saindhava lavana for } 3 \\
\text { days. }\end{array}$ & RRS 2/59 \\
\hline 06 & $\begin{array}{l}\text { Shilajatu } \\
\text { (Mineral pitch) }\end{array}$ & Shodhana & $\begin{array}{l}\text { Shilajatu is washed with a solution of water(10part) +Trikshara (equal } \\
\text { quantity of yavakshara, sarjikshara and tankana), with gomutra and with } \\
\text { kanji. }\end{array}$ & RRS 2/107 \\
\hline 07 & Shilajatu & Shodhana & $\begin{array}{l}\text { A big vessel filled half with equal quantity of Ksharodaka, kanji and } \\
\text { Guggulu. Its mouth is tied with a cloth upon which Shilajatu pieces are kept } \\
\text { and then it is covered with a sharava and sealed. Then the pot is heated } \\
\text { under mild fire for } 1 \text { hour due to which shilajatu melts in the solution. Later } \\
\text { shiljatu is filtered and washed with clean water. }\end{array}$ & RRS 2/109 \\
\hline 08 & $\begin{array}{l}\text { Chapala } \\
\text { (Bismuth ore) }\end{array}$ & $\begin{array}{l}\text { Satvapatana } \\
\text { (extraction of } \\
\text { essence of Bismuth } \\
\text { ore) }\end{array}$ & $\begin{array}{l}\text { Powder of Chapala is grinded with Kanji, swarasa of Visha and Upavisha } \\
\text { dravya. Bolus made is subjected to heat. }\end{array}$ & RRS 2/141 \\
\hline 09 & $\begin{array}{l}\text { Kharpara (or } \\
\text { Rasaka)(Zinc } \\
\text { ore) }\end{array}$ & Shodhana & $\begin{array}{l}\text { Rasaka heated in intense fire and dipped in either naramutra/takra/kanji for } \\
7 \text { times. }\end{array}$ & RRS 2/149 \\
\hline 10 & Kharpara & Satvapatana & $\begin{array}{l}\text { Powder of Haridra, Triphala, Raal(sarjarasa), Saindhava, Grhidhuma, } \\
\text { Tankana, Bhallataka (each half part) and Sudha Kharpara (one part) grinded } \\
\text { in Kanji and Nimbuswarasa. This paste is applied on Vrintakamusha and } \\
\text { dried. Musha is covered with sharava(mud saucer) and ignited with } \\
\text { charcoal. When the flame turns to blue and white colour, musha is taken out } \\
\text { carefully with the help of holder. Satva similar to vanga is collected. }\end{array}$ & $\begin{array}{l}\text { RRS } \\
2 / 151-153\end{array}$ \\
\hline
\end{tabular}

Uparasa - This includes Gandhaka (Sulphur), Gairika(Red ochre), Kasisa (Green vitriol), Kankshi(Alum), Haratala (Orpiment), Manahshila (Realgar), Anjana and Kankushtha. ${ }^{[10]}$ These drugs are very important in Rasashastra because without using these drugs, all the alchemical procedures are impossible. Usefulness of kanji in Uparasa varga processing is described in Table 4 
Table 4, showing the Utility of Kanji in Uparasa

\begin{tabular}{|c|c|c|c|c|}
\hline Sl.no. & Uparasa name & Purpose & Method & Reference \\
\hline 01 & $\begin{array}{l}\text { Kasisa }(\text { Green } \\
\text { vitriol) }\end{array}$ & Satvapatana & Same as Sphatika satvapatana. & RRS 3/57 \\
\hline 01 & $\begin{array}{l}\text { Sphatika } \\
\text { (PotashAlum) }\end{array}$ & Shodhana & Sphatika is soaked in kanji for 3 days. & RRS 3/66 \\
\hline 02 & Sphatika & Satvapatana & $\begin{array}{l}\text { Sphatika is grinded with kshara and amla varga dravya (kanji or } \\
\text { chanakamla) - made into bolus form and kept in musha to give intense heat }\end{array}$ & $\begin{array}{l}\text { RRS*3/64- } \\
65\end{array}$ \\
\hline 03 & $\begin{array}{l}\text { Haratala } \\
\text { (Orpiment) }\end{array}$ & Shodhana & $\begin{array}{l}\text { Small pieces of haratala }+1 / 10^{\text {th }} \text { part of Tankana(borax) }- \text { wash with nimbu } \\
\text { swarasa and kanji }- \text { then it is tied in a four folded cloth and swedana in } \\
\text { dolayantra with churnodaka and kanji as liquid media for } 8 \text { prahara. }\end{array}$ & $\begin{array}{l}\text { RRS } 3 / 75- \\
76\end{array}$ \\
\hline 04 & $\begin{array}{l}\text { Manashila } \\
\text { (Realgar) }\end{array}$ & Shodhana & $\begin{array}{l}\text { Swedana in dolayantra with with goat's urine for } 1 \text { prahara each- later } \\
\text { washed with Kanji. }\end{array}$ & RRS 3/96 \\
\hline 05 & $\begin{array}{ll}\text { All uparasa } \\
\text { drugs }\end{array}$ & $\begin{array}{l}\text { Samanya rasa } \\
\text { uparasa } \\
\text { shodhana }\end{array}$ & $\begin{array}{l}\text { Swarasa or kwatha of any one of the drug Suryavarta, Kadali, } \\
\text { Bandhyakarkoti, Koshataki, Devadali, Shigru, Vajrakanda, Jalapippali, and } \\
\text { Kakamachi is used for grinding Rasa and Uparasa drugs along with Kshara } \\
\text { (yavakshara) and amla dravya (Nimbuswarasa or Kanji). }\end{array}$ & $\begin{array}{l}\text { RRS* } \\
3 / 118-119\end{array}$ \\
\hline
\end{tabular}

Sadharana rasa: This group includes Kampillaka (Indian Kamala), Gauripashana (Arsenic oxide), Navasadara (Ammonium oxide), Kaparda (Cowrie), Agnijara (Ambergris), Girisindura (Red oxide of mercury), Hingula (Cinnabar) \& Mridarashringa (Litharge) ${ }^{[11]}$ drugs. Kanji utility in Sadharana rasa group is shown in Table 5

Table 5, showing the utility with reference to Sadharana rasa

\begin{tabular}{|l|l|l|l|l|}
\hline Sl.no & $\begin{array}{l}\text { Drug } \\
\text { Name }\end{array}$ & Purpose & Method & Reference \\
\hline 01 & Varatika & Shodhana & Swedana in Dolayantra with Kanji as liquid media for 1 yama (3hours). & RRS 3/137 \\
\hline 02 & Hingula & Shodhana & $\begin{array}{l}\text { Bhavana with sheep's milk, amlavarga dravya (nimbu swarasa) or Kanji for 7 times. } \\
\text { Later dried under the sun. }\end{array}$ & $\begin{array}{l}\text { RRS* } \\
3 / 143\end{array}$ \\
\hline
\end{tabular}

Ratna: Ratna(gems stones) is of nine types viz, Manikya (ruby), Mukta (pearl), Pravala (coral), Tarkshya (emerald), Pushparga (topaz), Vajra (diamond), Nilama (sapphire), Gomeda(zircon) and Vaidurya(cat's eye). ${ }^{[12]}$ Kanji used in different Ratna processing is given in Table 6

Table 6, showing the Kanji with reference to Ratna

\begin{tabular}{|l|l|l|l|l|l|}
\hline Sl.no & $\begin{array}{l}\text { Ratna } \\
\text { Name }\end{array}$ & Purposee & Method & Reference \\
\hline 01 & Manikya & Shodhana & Swedana in amlika rasa (kanji) for one prahara & $\begin{array}{l}\text { RRS* 4/60 } \\
-83\end{array}$ \\
\hline 02 & Pushparaga & Shodhana & Swedana in dolayantra in equal quantity of kulatha kwatha and kanji for 3 hours. & RRS 4/64 \\
\hline 03 & All ratna & Ratna druti & $\begin{array}{l}\text { Ratna (any ratna whose druti needs to be prepared) is placed at the centre of kalka } \\
\text { prepared out of Hingu, Panchalavana (saindhava lavana, samudra lavana, vida } \\
\text { lavana, souvarchala lavana and romaka lavana), Trikshara, Amlavetasa, } \\
\text { Chullikalavana (navasadara), Kumbhiphala (jayapala seeds), Jvalamukhi } \\
\text { (bhallataka), Vamshalochana, Dravanti, Rudanti, Payasya, Chitramulaka, } \\
\text { Snuhiksheera and Arkaksheera. Then the bolus is covered with Bhurjapatra and cloth } \\
\text { tightly and subjected to Swedana in dolayantra with Amlavarga dravya and kanji for } \\
\text { 3days. }\end{array}$ & $\begin{array}{l}\text { Vajra powder is kept in middle of kalka prepared from Vajravalli. It is } \\
\text { tied tightly with Bhurjapatra and cloth. Later Swedana in dolayantra with amlavarga } \\
\text { dravya and kanji for 7days }\end{array}$ & $\begin{array}{l}\text { RRS* 4/72 } \\
(84)\end{array}$ \\
\hline 04 & Vajra & Vajradravana & \\
\hline
\end{tabular}

Uparatna: These are known as semiprecious gems. There are different opinions regarding the numbers of uparatna. As per Rasatarangini, ${ }^{[13]}$ Uparatna is classified as Vaikranta (tourmaline), Suryakanta (sun stone), Chandrakanta (moon stone), Nripopala (lapis lazuli), Perojaka (turquoise), Sphatika(quartz). Among these kanji is mainly used in Vaikranta druti(conversion of mineral into liquid state) as given in Table 7. 
Table 7, showing the utility in Uparatna

\begin{tabular}{|l|l|l|l|l|}
\hline Sl.no. & Uparatna & Purpose & Method & Reference \\
\hline 01. & Vaikranta & Vaikranta druti & $\begin{array}{l}\text { Vaikranta churna is placed inside the kalka prepared of Ketaki } \\
\text { swarsa,saindhava lavana, Swarnapushpi and Indragopa. Then Swedana in } \\
\text { dolayantra with amlavarga and Kanji for 7 days. }\end{array}$ & $\begin{array}{l}\text { RR/76 } \\
4 / 7\end{array}$ \\
\hline 02. & Vaikranta & $\begin{array}{l}\text { Ashta Loha or vajra } \\
\text { dravana with vaikranta } \\
\text { druti }\end{array}$ & $\begin{array}{l}\text { Vaikranta druti is added with eight loha bhasma or with Vajra bhasma- tied } \\
\text { with Bhurjapatra and cloth- swedana in amlavarga and Kanji for 7 days }\end{array}$ & RRS 4/77 \\
\hline
\end{tabular}

Lohavarga: Loha means to extract the metals from their ores or to extract dosha from the body. ${ }^{[14]}$ Mainly metals and alloys are included is this group, so it is also known as Dhatu varga. Svarna (gold), Rajata (silver), Tamra(copper), Loha(iron),
Naga (lead), Vanga (tin), Pittala (brass), Kamsya (bell metal) and Vartalauha comes under this group. Utility of kanji in various processings of Lohavarga is described in Table 8.

Table 8, showing the utility with reference to Loha.

\begin{tabular}{|l|l|l|l|l|l|}
\hline Sl.no. & $\begin{array}{l}\text { Name of } \\
\text { Loha }\end{array}$ & Purpose & Method & Reference \\
\hline 01 & $\begin{array}{l}\text { All the } \\
\text { lohas }\end{array}$ & $\begin{array}{l}\text { Samanya } \\
\text { shodhana of } \\
\text { lohas }\end{array}$ & $\begin{array}{l}\text { Thin sheets of ashuddha dhatu are to be heated in intense fire and dipped in each of the } \\
\text { following liquid media consecutively for 7 times- tila taila, takra, gomutra, kanji and } \\
\text { kulattha kwatha. }\end{array}$ & RRS 5/11 \\
\hline 02 & Tamra & Shodhana & $\begin{array}{l}\text { Paste of Saindhava lavana and Nimbuswarasa are applied over the tamra patra. It is } \\
\text { then heated and dipped in kanji for 8 times. }\end{array}$ & RRS 5/49 \\
\hline 03 & Loha & Marana & $\begin{array}{l}\text { Paste of Shuddha Hingula and breast's milk is applied over the Loha patra. It is dried } \\
\text { and subjected to gajaputa. Next day loha churna is taken out in a khalwa yantra added } \\
\text { with 1/20 } \\
\text { swars part of Shuddh Hingula and bhavana is given with Triphala kwatha, jambira } \\
\text { repeated for 40 times with each time recording the weight of Loha churna. }\end{array}$ & $\begin{array}{l}\text { RRS } \\
5 / 110-112\end{array}$ \\
\hline 04 & Naga & Marana & $\begin{array}{l}\text { Suddha naga is taken and melted in iron vessel. Then 1/4th part of Ashwath twak and } \\
\text { Chincha twak bhasma are added gradually by stirring through iron ladle till naga } \\
\text { converts into powder form. The collected ash of naga is washed with water 2-3 times } \\
\text { and dried. Later equal quantity of Suddha Manashila is added to Nagachurna and } \\
\text { levigation with Jambiriswarasa or kanji is done. Then it is subjected to kukkuta puta. } \\
\text { After it cools down 1/20 phart of manashila is added and bhavana with Nimbu swarsa } \\
\text { or Kanji is given for 3 hours to give kukkuta puta. This process is repeated for 60 times. }\end{array}$ & 5/179-181 \\
\hline 05 & Pittala & $\begin{array}{l}\text { Grahya } \\
\text { lakshana }\end{array}$ & $\begin{array}{l}\text { Ritika pittala on heating and quenching in kanji it turns into tamra(red) colour. } \\
\text { Kakatundi pittala on heating and quenching in kanji it turns into Krishna (black) colour. }\end{array}$ & $\begin{array}{l}\text { RRS } \\
5 / 191-193\end{array}$ \\
\hline 06 & Kamsya & Marana & $\begin{array}{l}\text { Bhavana of trikshara and panchalavana with nimbu swarasa or kanji for 7 times. Then } \\
\text { this paste is applied over the suddha Kamsya patra and closed in sharava samputa } \\
\text { which is to be subjected to gajaputa. }\end{array}$ & $\begin{array}{l}\text { RRS* } \\
5 / 209-210\end{array}$ \\
\hline
\end{tabular}

Ankolabeeja tailapatana: Acharya Ankola seeds (Alangium Salvifolium linn.f) vagbhata, author of Rasa Ratna Samucchaya using Kanji as liquid media as described in has also explained the extraction of oil from Table 9

Table 9, Kanji in Ankola beeja tailapatana.

\begin{tabular}{|l|l|l|}
\hline $\begin{array}{l}\text { Method } \\
1\end{array}$ & $\begin{array}{l}\text { Indravaruni root powder (Citrullus colocynthis) is mixed in kanji later Ankola seed in fine powder form is added to } \\
\text { it and kept under sun. Due to sunheat ankolabeeja taila will float over the kanji which collected with suitable } \\
\text { method. }\end{array}$ & $\begin{array}{l}\text { RRS } \\
5 / 234\end{array}$ \\
\hline $\begin{array}{l}\text { Method } \\
2\end{array}$ & $\begin{array}{l}\text { Kalka of Indravaruni and Petkari leaves are by adding kanji. Ankolabeejamajja is pounded in khalwa yantra which } \\
\text { is later kept in between the kalka made before and tied in thin cloth. This pottali is tied in a stand and kept under } \\
\text { the sun. The taila is collected in a glass vessel. }\end{array}$ & $\begin{array}{l}\text { RRS } \\
5 / 235\end{array}$ \\
\hline $\begin{array}{l}\text { Method } \\
3\end{array}$ & $\begin{array}{l}\text { Ankolabeejamajja is finely powdered, grinded with kanji and left overnight. Next morning the kalka is taken in a } \\
\text { pottali and swedana in kandukayantra for 2 hours is done. Then kalka is tied in a strong cloth and pressed with a } \\
\text { wodden log. The drained out taila is collected in a glass vessel }\end{array}$ & $\begin{array}{l}\text { RRS } \\
5 / 237- \\
239\end{array}$ \\
\hline
\end{tabular}

Preparation of RasaLinga (Raseshwara): 1 part of gold leaf and 3 parts of mercury are to be levigated with sour juices for 3 hours. When this mixture gets solidified, an oval shaped like linga of Lord Shiva is made and this linga is kept inside lemon. This is then subjected to swedana in dolayantra with kanji as liquid media for 1 day. Next day Raseshwara is taken out and washed with water and placed at the centre platform like arrangement of Rasa mandapa. ${ }^{[15]}$

Worship of instruments: Vida, Kanji, Yantra, Lavana, Koshti, Musha, Vankanala, 
Tusha, Vanyopala, Bhastrika, Khalwa yantra, Vessels, Divya aushadhis etc. should be worshipped at the entrance of Rasa mandapa. ${ }^{[16]}$

Parada- In Rasashastra, Parada (mercury) has miraculous and mythical importance as the whole branch is named after Parada. Procedures which are being adopted to add or alter the qualities present in the drug is called as samskara. ${ }^{[17]}$ Utility of kanji in the eight samskara of Parada (eight basic processing steps of mercury) (swedana, mardana, murchhana, utthapana, patana, bodhana, niyamana and deepana), ${ }^{[18]}$ in jalauka bandha (stable mercury) (one of the process where mercury is converted from liquid to solid state $)^{[19]}$ and in preparation of Parada Bhasma (incineration of mercury) has been explained in the Table 10 .

Table 10 showing utility of Kanji in Parada Samskara

\begin{tabular}{|c|c|c|c|}
\hline Sl.no. & Sanskara & Procedure & Reference \\
\hline 01 & $\begin{array}{l}\text { Swedana (boiling } \\
\text { in liquid media) }\end{array}$ & $\begin{array}{l}1 \text { part of suddha parada is kept in a bolus made from } 1 / 16^{\text {th }} \text { part each of shunti, pippali, } \\
\text { maricha, saindhava lavana, rajika, chitraka mula, ardraka and mulaka. It is then sbjected to } \\
\text { swedana in dolayantra with kanji as media for } 3 \text { days. }\end{array}$ & $\begin{array}{l}\text { RRS } 8 / 57 \\
\text { RRS } 11 / 26\end{array}$ \\
\hline 02 & $\begin{array}{l}\text { Maradana } \\
\text { (trituration) }\end{array}$ & $\begin{array}{l}1 \text { part of Swedita Parada and } 1 / 16^{\text {th }} \text { part of Grihadhuma, Ishtika churna, Godadhi, Guda, } \\
\text { Saindhava lavana, Rajika are grinded with Kanji in khalwa yantra for } 3 \text { days. }\end{array}$ & $\begin{array}{lr}\text { RRS } & 8 / 58 \\
\text { RRS } & 11 / 27- \\
30 & \\
\end{array}$ \\
\hline 03 & $\begin{array}{l}\text { Utthapana } \\
\text { (regaining of } \\
\text { original form of } \\
\text { parada) }\end{array}$ & $\begin{array}{l}\text { Murchchita Parada (Parada not in its original form) is placed in urdhwapatana yantra and } \\
\text { subjected to heat. Urdhvapatita parada is collected and boiled in kanji. }\end{array}$ & $\begin{array}{l}\text { RRS 8/61 } \\
\text { RRS } 11 / 33\end{array}$ \\
\hline 04 & $\begin{array}{l}\text { Adhapatana } \\
\text { (Downward } \\
\text { sublimation) }\end{array}$ & $\begin{array}{l}1 \text { part parada and } 1 / 16^{\text {th }} \text { part Triphala, Shigru, Chitraka, Saindhavalavana, Rajika are taken } \\
\text { grinded in a khalwa yantra with kanji as media. This paste is applied on the inner surface of } \\
\text { upper pot and subjected to give heat in adhapatana yantra. }\end{array}$ & RRS 11/36 \\
\hline 05 & Adhapatana II & $\begin{array}{l}1 \text { part of Parada and } 1 / 16^{\text {th }} \text { part each of Haridra, Ankolabeeja, Aragvada, Gritakumari, } \\
\text { Amalaki, Haritaki, Vibhitaki, Chitrakamula, Tanduliya, Punarnava mula, Hingu, Saindhava } \\
\text { lavana, and Swarna makshika are take and made into paste form for adhapatana. }\end{array}$ & $\begin{array}{l}\text { RRS } 11 / 37- \\
38\end{array}$ \\
\hline 06 & $\begin{array}{l}\text { Tiryakpatana } \\
\text { samskara } \\
\text { (transverse } \\
\text { sublimation) }\end{array}$ & $\begin{array}{l}\text { Parada collected from above method is pounded with abhraka patra and kanji. Then it is } \\
\text { kept in tiryak patina yantra for } 3 \text { hours. Later Parada collected is boiled with Kanji in dola } \\
\text { yantra for } 3 \text { hours. Again Parada is made into pishti form with Dhanyabhraka and subjected } \\
\text { in adhapatana yantra. }\end{array}$ & $\begin{array}{l}\text { RRS 11/41- } \\
43\end{array}$ \\
\hline 07 & $\begin{array}{lr}\text { Niyamana- } & \text { I } \\
\text { (restraining } & \text { by } \\
\text { boiling in liquid } \\
\text { media) }\end{array}$ & $\begin{array}{l}1 \text { part of Parada and } 1 / 16^{\text {th }} \text { part of Karkoti, Sarpakshi, Vrichachikali, Saindhana lavana, } \\
\text { Bhringaraja are taken, made into paste form and tied in a pottali. It is subjected to swedana } \\
\text { with kanji in dolayantra for } 3 \text { days. }\end{array}$ & RRS 11/46 \\
\hline 08 & Niyamana-II & $\begin{array}{l}1 \text { part of Parada and } 1 / 16^{\text {th }} \text { part of Marichachurna, Sphatika, Kasisa, Saindhava lavana, } \\
\text { Rajika, Shigru twak, Tankana are taken made in paste form tied in pottali. It is subjected to } \\
\text { swedana with Kanji in dola yantra for } 3 \text { days. }\end{array}$ & RRS 11/47 \\
\hline 09 & $\begin{array}{l}\text { Dipana } \\
\text { (appetisation by } \\
\text { boiling in liquid } \\
\text { media) }\end{array}$ & $\begin{array}{l}1 \text { part of Parada and } 1 / 16^{\text {th }} \text { part each of Yavakshara, Sarjikshara, Tankana, Saindhava } \\
\text { lavana, Kasisa, Sphatika, Chitraka, Shigru, Rajika, Pippali, Amlavetasa, Lakucha, } \\
\text { Saindhava lavana, Maricha, Jambiri nimbu are taken, made in paste form. A big mud pot is } \\
\text { taken filled with Kanji is taken and Abhraka patra along with above prepared kalka are } \\
\text { added to it. Pot is sealed and left undisturbed. }\end{array}$ & $\begin{array}{lr}\text { RRS } & 8 / 65 \\
\text { RRS } & 11 / 48- \\
49\end{array}$ \\
\hline 10 & Jalauka bandha & $\begin{array}{l}\text { 105gm of Parada should be taken and grinded } 1 \text { day each with Ankolakvrikshtwak kwatha, } \\
\text { Aragwadha vriksh twak kwata, Gritakumari swarasa. Bakuchi, Haridra, Kokilaksha, } \\
\text { Apamarga and Dhattura are to be taken equal in quantity to that of Parada and made into } \\
\text { powder form. All the drugs added to Parada and mardana to be done for } 21 \text { days with Kanji } \\
\text { (prepared from } 1 / 4^{\text {th }} \text { Haridra churna by kwatha procedure). Then jalauka are to be prepared } \\
\text { from this. }\end{array}$ & $\begin{array}{l}\text { RRS } \\
11 / 101-103\end{array}$ \\
\hline 11 & Parada bhasma & $\begin{array}{l}\text { Equal quantity of Devadali and Vishnukranta panchanga are to be pounded with kanji and } \\
\text { their juice needs to be extracted. Parada placed in sharava is kept over stove and this juice is } \\
\text { poured carefully with continuous stirring. After some time mardita parada will turn into } \\
\text { solid white form like lavana. }\end{array}$ & $\begin{array}{l}\text { RRS } \\
11 / 116-117\end{array}$ \\
\hline
\end{tabular}

Valabhi yantra: In the context of Yantra adhyaya, Acharaya has described Valabhi yantra where kanji needs to be filled in the gap between the two iron vessel (one and one big) which are separated with 2-3 stones in between them. Handle of both the vessel is tied together. Murcchita Parada is kept in small vessel and heated for 6 hours. ${ }^{[20]}$

Utility of kanji in various useful formulations has been summarized in Table 11. 
Ankita Prajapati et.al. Utility of kanji as per rasaratna samuchchaya - an extensive review.

Table 11 showing utility of kanji in the formulations.

\begin{tabular}{|c|c|c|c|}
\hline Sl.no & Yoga & Utility of kanji & Reference \\
\hline 01. & Lokanatha gutika & $\begin{array}{l}\text { Kanji as bhavana media } \\
\text { Kanji as swedana media } \\
\text { Kanji as prakshalana media }\end{array}$ & RRS $12 / 81-82$ \\
\hline 02. & Arshohara yoga-1 & Kusumbha patra cooked with kanji - internal use & RRS 15/81 \\
\hline 03. & Devadalyadi lepa & $\begin{array}{l}\text { Devadali with equal quantity of Saindhava lavana, grind with Kanji for } \\
\text { lepa(external application) }\end{array}$ & RRS $15 / 82$ \\
\hline 04. & Durnaamhara lepa & Katutumbi beeja grinded with kanji and guda, use for lepa & RRS 15/87 \\
\hline 05. & Vajradhara rasa & Kanji as anupana in sangrahani roga. & RRS 16/94-96 \\
\hline 06. & Vaishawanara pottali rasa & Kanji is contraindicated. & RRS 16/111-116 \\
\hline 07. & Haridra yoga & $\begin{array}{l}\text { Haridra churna and Guda grinded with jala/Kanji for internal administration } \\
\text { in mutrasharkara and mutrakricha roga. }\end{array}$ & RRS $17 / 26$ \\
\hline 08. & Tamra yoga & Swedana in dolayantra with kanji as liquid media. & RRS $17 / 31-32$ \\
\hline 09. & Udayabhaskara rasa & In case of agnimandya-Kanji and taila is indicated as anupana. & RRS $17 / 108-116$ \\
\hline 10. & Sarvamayahara rasa & Mardana with Kanji for 2 days. & RRS 18/17-24 \\
\hline 11. & Kanchini prayoga & Anupana madya or Kanji in plihavriddhi roga. & RRS 18/99 \\
\hline 12. & Sadya soolahara yoga & $\begin{array}{l}\text { Sauvarchalalavana churna with Kanji for internal administration to alleviate } \\
\text { shula. }\end{array}$ & RRS $18 / 171$ \\
\hline 13. & Agnikumar rasa & $\begin{array}{l}\text { If daha occurs due to this medicine, then internal administration of } \\
\text { meghanada shaak moolaswarasa, sita, yashti,swetachandana, tankana with } \\
\text { Kanji in sthoulya. }\end{array}$ & RRS 18/183-201 \\
\hline 14. & Tamradhruti rasa & Anupana takra/Kanji in amlapitta. & RRS 18/208-217 \\
\hline 15. & Vajrakshara & $\begin{array}{l}\text { In tridosha agnimandhya and ajeerna, vajrakshara is given with Kanji in } 2 \\
\text { nishka pramana }(6 \mathrm{gm}) \text {. }\end{array}$ & RRS 19/32-37 \\
\hline 16. & Medanisara rasa & Swedana in dolayantra with Kanji as media for 12 hours. & RRS 20/120-126 \\
\hline 17. & Ankoladi lepa & $\begin{array}{l}\text { Paste of Gunjabeeja churna and chitrakamula churna with Kanji. Indicated in } \\
\text { switrakushta. }\end{array}$ & RRS 20/211 \\
\hline 18. & Martandeshwara rasa & $\begin{array}{l}\text { Equal quantity of Jeernatamra churna and Swarnamakshika churna taken and } \\
\text { grinded with Nimdu swarasa or Kanji. }\end{array}$ & RRS 21/62-68 \\
\hline 19. & Vijayabhairava taila -I & $\begin{array}{l}\text { Kajjali is added with Haratala and Manashila and grinded with Kanji for } 1 \\
\text { day. Indicated in kampavata and all vatarogas. Given } 10 \text { drops in milk. }\end{array}$ & RRS 21/148 \\
\hline 20. & Vijayabhairava taila - II & $\begin{array}{l}\text { Method of preparation same as Vijayabhairava taila -I. Given 7-8 drops in } \\
\text { Tambulapatra. Indicated in bahukampa, shirokampa, ekangavata. }\end{array}$ & RRS 21/149-151 \\
\hline 21. & Suta taila & $\begin{array}{l}\text { Kajjali is added with Haratala and Manashila grinded well. Then it is grinded } \\
\text { with Kanji for } 2-3 \text { hours. Indicated in bahukampa and shirokampa both } \\
\text { internal administration and external application. }\end{array}$ & RRS 21/152-156 \\
\hline 22. & Vardhaman rasa & $\begin{array}{l}\text { Purified gold and copper subjected to intense heating in musha and then } \\
\text { dipped in tila taila, takra, gomutra, Kanji and Kulattha kwatha for } 7 \text { times in } \\
\text { each media. Indicated in yoniroga }\end{array}$ & RRS 22/30-40 \\
\hline 23. & $\begin{array}{l}\text { Jwaradiroga nashanartha in } \\
\text { sadyojata balaka }\end{array}$ & Towel soaked in Kanji is used to wipe baby's body for 2-3 times & RRS 22/131 \\
\hline 24. & Grihadhuma kwatha & $\begin{array}{l}\text { Decoction prepared with grihaduma and kanji. Used for gandusha in } \\
\text { mukhadurgandha }\end{array}$ & RRS 24/43 \\
\hline 25. & Aranala gandusha & $\begin{array}{l}\text { Kanji is boiled by adding little amount of saindhava lavana. Used for } \\
\text { gandusha in mukhavairasya. }\end{array}$ & RRS 24/52 \\
\hline 26. & Tailakanjika gandusha & $\begin{array}{l}\text { Kanjika and lavana used for gandusha in tambula churnadagdha in mouth } \\
\text { ulcers. }\end{array}$ & RRS 24/53 \\
\hline 27. & Ravitandava & $\begin{array}{l}\text { Tamra patra shodhana as per samanya shodhana procedure. Indicated in } \\
\text { bhagandara }\end{array}$ & RRS 24/110-113 \\
\hline 28. & Vishnukrantadi lepa & $\begin{array}{l}\text { Equal quantity of Aparajita and petarivriksha bark are taken ans grinded with } \\
\text { kanji. It is applied over kalasphota and granthi }\end{array}$ & RRS 24/132 \\
\hline 29. & Upadamshadi pratikara & Samudra lavana is grinded with kanji. Used for external application. & RRS 25/75 \\
\hline 30. & Swarna and roupya shodhana & $\begin{array}{l}\text { Paste of Panchamrittika and nimbu/kanji is applied over swarna patra, dried } \\
\text { and given laghuputa. }\end{array}$ & RRS 28/4 \\
\hline 31. & Tamra bhasma & $\begin{array}{l}\text { Shudhha tamra patra is cooked with gomutra in staliyantra for } 3 \text { hours. Then } \\
\text { paste of gandhaka and Nimbu swarasa/Kanji is applied over tamra patra and } \\
\text { subjected to gajaputa. Total } 15 \text { puta has been told. }\end{array}$ & RRS 28/11 \\
\hline 32. & Lohamarana vidhi & Tamra and Dhanyabhraka is given intense heat and quenched in kanji & RRS 28/101 \\
\hline 33. & Parada jarana & Dhanyabhraka is given bhavana with kanji for 7 times. & RRS 30/16-20 \\
\hline 34. & Rasaklapa (ajerna) & $\begin{array}{l}\text { Rasasindura with madhu; paste of kanji with Erandamulakwatha and Haritaki } \\
\text { churna. Given for internal administration. }\end{array}$ & RRS 30/35 \\
\hline 35. & Rasakalpa (pakshmashate) & $\begin{array}{l}\text { Karpasabeejamajja }-7 \text { parts Pippali churna }-1 \text { part mixed together and } \\
\text { pounded with kanji in a khalwa yantra and allowed to dry. Indicated to apply } \\
\text { over eyelashes. }\end{array}$ & RRS 30/62 \\
\hline 36. & (vishadigdha & $\begin{array}{l}\text { A thick cloth is taken, it is washed with chanakamala and dried. Equal } \\
\text { quantity of Bakuchipatra, chakramarda patra, Karpasa patra and Agastaya } \\
\text { patra are taken and kept over the cloth. It is then soaked in kanji and } \\
\text { macerated with hand after adding Parada bhasma. }\end{array}$ & RRS 30/81-82 \\
\hline 37. & Parada bhakshana kala apathy & Kanji is contraindicated in Parada bhakshana kala. & RRS 30/107 \\
\hline
\end{tabular}




\section{DISCUSSION}

According to translator and editor DA Kulkarni, Kanji can be taken for the procedure where ever amla dravya has been mentioned in the verse. On the other way commentator Siddhinanadan Mishra has explained lemon juice can be taken where ever amla dravya mentioned in the verse. Kanji is utilized right from the purification method of minerals, metals, gems stone, etc. to the making of gems stone druti. Kanji is also used as media to test the type of Pittala which should be used for processing. Kanji is one of main media in the eight basic processing steps of mercury, in jalauka bandha and in incineration of mercury. Kanji is used in the preparation of Raseshwara (rasalinga) and it is said to be worshipped at the entrance of Rasa Mandapa. Kanji is used in process of extraction of oil and it has also been described in the context of Valabhi yantra. Kanji is used in preparation of various formulations. Kanji is said to be contraindicated during parada sevana kala.

\section{CONCLUSION}

Kanji having the properties like tikshna, samghata-bhedana and shaithilikarana possess the wide applicability in multiple procedures of Rasashastra. Due to its acidic nature, it helps to break the hard mantle of metals. It makes the metals brittle and soft thus making it suitable for further processes. It has been utilized as different media in many of the formulations.

\section{Acknowledgement: None}

\section{Conflict of Interest: None}

\section{Source of Funding: None}

\section{REFERENCES}

1. Ambikadatta shastry. Sushruta samhita. Varanasi: Chaukambha Sanskrit Samsthana; 2001, Kritanna varga 45/214: 213.

2. Shyamasundaracharya Vaishya. Rasayanasara vol I. $7^{\text {th }}$ ed. Varanasi: chowkhamba krishnadas academy; 2005. Paribhasha prakarana, verse 55-60: 59.

3. Amarasimha. Amarakosa with Ramasrami (vyakhyasudha) commentary by Bhanuji diksita. Varanasi: Chaukhamba Publications; 2012. Kanda 2, Varga 9, Verse 39: 417.

4. Acharya Dhundhuk Nath. Rasendra chintamani with Siddhiprada hindi translation by prof. siddhi nandan Mishra. Varanasi: chaukhambha orientalia. Chapter 3 Bandhanaadhyaya, verse 15-18: 19.

5. Santhosh B et al. Kanji: An Ayurvedic Fermentive Preparation. International Research Journal of Pharmacy. 2012; 3(1):154-155.

6. Acharyah Shree Vagbhst. Rasa Ratna Samuchchayah with Siddhiprada hindi commentary by Prof. Siddhi Nandan Mishra. $1^{\text {st }}$ ed. Varanasi: chaukhambha orientalia; 2011.

7. Acharya Vagbhat. Rasa Ratna Samuchchayah Vol I with Vigyanbodhini commentary by Prof. Dattatraya Anant Kulkarni. New Delhi: Meharchand Lachhmandas Publications; 2017.

8. Acharyah Shree Vagbhat. Rasa Ratna Samuchchayah with Siddhiprada hindi commentary by Prof. Siddhi Nandan Mishra. $1^{\text {st }}$ ed. Varanasi: Chaukhambha Orientalia; 2011. Chapter 2, verse 1:27.

9. Acharyah Shree Vagbhat. Rasa Ratna Samuchchayah with Siddhiprada hindi commentary by Prof. Siddhi Nandan Mishra. $1^{\text {st }}$ ed. Varanasi: Chaukhambha Orientalia; 2011. Chapter 10, verse 93:249.

10. Acharyah Shree Vagbhat. Rasa Ratna Samuchchayah with Siddhiprada hindi commentary by Prof. Siddhi Nandan Mishra. $1^{\text {st }}$ ed. Varanasi: Chaukhambha Orientalia; 2011. Chapter 3, verse 1:60.

11. Acharyah Shree Vagbhat. Rasa Ratna Samuchchayah with Siddhiprada hindi commentary by Prof. Siddhi Nandan Mishra. $1^{\text {st }}$ ed. Varanasi: Chaukhambha Orientalia; 2011. Chapter 3, verse 123124:85.

12. Acharyah Shree Vagbhat. Rasa Ratna Samuchchayah with Siddhiprada hindi commentary by Prof. siddhi nandan Mishra. $1^{\text {st }}$ ed. Varanasi: Chaukhambha Orientalia; 2011. Chapter 4, verse 6:96.

13. Shri Sadananda Sharma. Rasa Tarangini with Rasavigyana Hindi translation by Pandit Dharmananda Shastry. New Delhi: 
Motilala Banarasidas Publications; 2012.Chapter 23, verse 154:632.

14. Acharyah Shree Vagbhat. Rasa Ratna Samuchchayah with Siddhiprada hindi commentary by Prof. Siddhi Nandan Mishra. $1^{\text {st }}$ ed. Varanasi: Chaukhambha Orientalia; 2011. Chapter 5, verse 1:141.

15. Acharyah Shree Vagbhat. Rasa Ratna Samuchchayah with Siddhiprada hindi commentary by Prof. Siddhi Nandan Mishra. $1^{\text {st }}$ ed. Varanasi: Chaukhambha Orientalia; 2011. Chapter 6, verse 2223:197.

16. Acharyah Shree Vagbhat. Rasa Ratna Samuchchayah with Siddhiprada hindi commentary by Prof. Siddhi Nandan Mishra. $1^{\text {st }}$ ed. Varanasi: Chaukhambha Orientalia; 2011. Chapter 6, verse 5155:200.

17. Agnivesha. Charaka Samhita, Revised by Charaka and Dridhabala with Ayurveda Dipika commentary of Chakrapanidatta. Varanasi: Chaukhambha Publications; 2014. Vimanastana Chapter 1, verse 21:235.
18. Shri Sadananda Sharma. Rasa Tarangini with Rasavigyana hindi translation by Pandit Dharmananda Shastry. New Delhi: Motilala Banarasidas Publications; 2012. Chapter 5, verse 44-45:93.

19. Acharyah Shree Vagbhat. Rasa Ratna Samuchchayah with Siddhiprada hindi commentary by Prof. Siddhi Nandan Mishra. $1^{\text {st }}$ ed. Varanasi: Chaukhambha Orientalia; 2011. Chapter 11, verse 58:273.

20. Acharyah Shree Vagbhat. Rasa Ratna Samuchchayah with Siddhiprada hindi commentary by Prof. Siddhi Nandan Mishra. $1^{\text {st }}$ ed. Varanasi: Chaukhambha Orientalia; 2011. Chapter 9, verse 47-49: 232.

How to cite this article: Prajapati A, Medikeri SS, Katti A. Utility of kanji as per rasaratna samuchchaya - an extensive review. Int J Health Sci Res. 2022; 12(2):137-145.

DOI: https://doi.org/10.52403/ijhsr.20220219 